\title{
The Effects of Fraud on Bank Efficiency and Customer Deposit in Nigerian Commercial Banks
}

\author{
Dipo- Ojo Oluwabunmi Adenike, Murdtadho. M. Alao
}

\begin{abstract}
This study investigated the impact of fraud on bank efficiency in Nigeria. Specifically, the paper aimed to determine the effect of fraud on customers' deposit and evaluates the impact of frauds on bank efficiency. To achieve these objectives a descriptive research design was adopted to gather secondary data for the study. The study covered the periods 2008-2017. The population for this study was made up of all Commercial banks in Nigeria from which a purposive sample size of five banks was selected. In addition, the Generalize Method of Moment (GMM) was adopted for the study. The result of the study obtained revealed that fraud had a sufficient negative effect on customers deposit in Nigeria banks and that the existence of fraud in Nigeria commercial banks hampered the efficiency of these banks. It was concluded that there was substantial evidence that fraud influenced banks efficiency negatively. It was recommended that the management of commercial banks or Deposit Money Banks (DMBs) in Nigeria should strength their existence internal control system in order to reduce the incidence of frauds in their banks.

Index Terms - Fraud, Customers' deposit, Commercial banks, Banks efficiency, GMM.
\end{abstract}

\section{INTRODUCTION}

The National Deposit Insurance Corporation (NDIC) annual report of 2017 revealed substantial increase in attempted frauds and forgeries in Nigeria banking sector from 16,757 in 2016 to 26,182 in 2017 a percentage increase of $56.3 \%$. The frauds and forgeries cases reported in 2017 also showed a $146.5 \%$ and $113.20 \%$ increase over reported cases in 2014 and 2015 respectively. Fraud is a serious issue that has adverse effects in the efficiency of Nigeria banking sector This appears to have caused serious setbacks to the nation's banking system. The incidence and prominence of failed banks in Nigeria banking sectors arising from bank fraud appears to have reduced customers' confidence which seem to have affected the nation's financial system. The erosion of depositors' confidence on bank as a result of prevalence of bank fraud in Nigeria seems to have resulted to customers operating spilt accounts among banks in Nigeria.

A lot of scholars had studies the impact of fraud on Nigerian bank such as Kanu and Okoroafor (2013, Aruomoaghe and Ikyume (2013) Owolabi (2010), Uche and Agbo (2013), Ikpefan (2006) discovered significant relationship between bank deposit and fraud while Uche and Agbo (2013) found that the percentage of mobilized fund lost to fraud was high between 2001-2006 but reduced between

Dipo- Ojo Oluwabunmi Adenike, Faculty of Business/ Accounting Studies Lincoln University College, Malaysia

Murdtadho. M. Alao, Deputy Registrar Lincoln University College, Malaysia
2006-2011. Okoye and Gbegi (2013) and Ademoye (2012) on their study of the impact of fraud on bank performance found devastating impact of fraud on bank performance with Inaya and Isito (2016) involvement on fraud Owolabi (2010) discovered that bank executives were involve in over 70 percent of the frauds in bank while the study by Inaya and Isito (2016) further revealed that banks staff do not see un-official borrowing and foreign exchange malpractices as a form of bank fraud. This paper is designed to investigate the impacts of bank fraud on the efficiency and sustainability of banking system in Nigeria. Specifically, this paper aims to; determine the effect of fraud on customers' deposit ad evaluate the impact of frauds on bank efficiency. Moreover, to investigate these objectives, the paper is divided into five parts which are the introduction, literature review, methodology, empirical results, conclusion and recommendation.

\section{A. Review of Related Literature}

The meaning attached to words is very essential in understanding the relationship between the words in relation to the subject matter under study. Hence, this section tries to give a clear definition to concepts that are related to the study.

Enofe, Abilogun \& Omoolorun (2017) stated that defining fraud is as difficult as identifying it. No definite and invariable rule can be laid down as a general proposition in defining fraud as it includes surprise, trick, cunning and unfair ways by which another is cheated. 'Fraud is to create a misjudgment or maintain an existing misjudgment to induce somebody to make a contract'. It involves enriching oneself intentionally by reducing the value/worth of an asset in secret.

Idowu (2009) also defined fraud as the deliberate falsification camouflage or exclusion of the truth for the purpose of dishonesty/stage management to the financial damage of an individual or an organization. The association of certified Fraud Examiners (1999) further defines fraud as the use of one's profession for personal enhancement through the conscious misuse, misapplication or employment of organizational possessions of property.

To Olatunji and Adekola (2014), fraud is any actions by which one person intend to gain a deceitful advantage over another. In other words, fraud is an act of commission which is planned to cause unlawful gain to one person and criminal loss to the other, either by way of concealment of information or otherwise. The Federal Bureau of Investigation (FBI) definition of fraud can be narrowed down to lying, stealing and cheating. In Nigeria, fraud is seen as the act of obtaining the assets and/or properties of another party by false pretense. According to Olatunji \& Adekola (2014), for instance in 1888 the United State Supreme Court inferred that fraud occurs 
when a defendant knowingly makes representation in regard to a material fact that is false and the complainant acts on this representation reasonably believing it to be true. According to United Kingdom (2006) fraud Act, fraud is committed in three ways namely: by false representation, failing to disclose information and abuse of position.

The Federal Bureau of investigation (FBI) in the United States views fraud as the act of obtaining the asset and/or properties of another party by false pretense. It is considered as a crime and also a civil law violation anywhere in the country ( Adeyemo, 2012).

According to Wanjohi (2014) fraud is classified in various ways using different staff viz: general manager, managing directors and the victims of such fraud are investors, creditors, and tax authorities. It is done via financial statement through creative accounting. There is also employee fraud/non-management type of fraud which is primarily committed by the employees of banks. Employee fraud is mainly characterized by cash theft from bank tills, forgeries of customers signature with the intention of withdrawing monies from the customers' accounts, opening and operating fictitious accounts and illegal transfer of funds to other accounts Tchnakova (2002) and Adeyemo (2012). There is also third-party fraud often committed by customers and non-customers of banks which may include; cheque fraud, kitting misrepresentation and impersonation counterfeit securities, money transfer fraud, clearing fraud, letter of credit fraud and card fraud. Bank frauds can be classified into three that is by flow, by victims and by act Idowu (2009).

Bank frauds seriously endanger the organizational growth of a bank as it leads to bank distress (Ojo 2008). This is because fraud reduces the deposits of depositors and ultimately leads to the erosion of capital base of banks. The cost of fraud is also usually difficult to estimate because not all frauds are discovered or even reported since most banks have a propensity to cover up till the frauds emanating from their banks, all in a bid to continue to gain customers goodwill and stimulate their clients' confidence all the time (Asukow 1999).

According to Adebayo \& Topson (2014), as cited by Popoola, Fakunle, Omole \& Oyedeji (2018) the cases of fraud and other fraudulent activities can be classified into primary and secondary. The primary causes of this dreadful conditions may linked to general level of corruption, outrageous unemployment, serious social decadence and wrong societal value system and deficient legal processes supported with bad governance. These causes are inter-related and with time they get holistic in nature. Corruption is an age long phenomenon and it is as old as human race. It has root in all ideology, moral, culture, polity and intellect. It has eaten deep into the society to the point of losing sights of its detrimental and parasitic symbiosis with many politics including Nigeria and their citizens all over the world Akindele (2005). Shogunle (2012) gives some features to identify corruptions and they are any crime carried out primarily for economic gain, any crime requiring some form of organization (i.e. interaction, no one man show; any crime involving the use or non-use or misuse legitimate power, authority, force, techniques or commerce industry or public service and administration).
Derogatory value system and social decadence which is also a form of a remote cause of fraud has plagued the country with misplaced value system; the sources of wealth of an average Nigerian is a thing of no consequence Adebayo \& Thompson (2014) while secondary cause of fraud are attributed to the direct consequences of plague of the primary causes and are often referred to as the immediate cause. Asukwo, (1999) listed the following as the causes of fraud in bank; greed which is a drive to acquire gains far beyond one's income and immediate or long-term needs; genetic cause, a hereditary characteristic passed from parents to offspring, poverty through poor income; poor internal control system which may include ineffective supervision, absence of timely audit, absence of operations manual, weak operational guideline, lack of proper training causing incompetence and error etc.

Finance business information 2018 also state that bank loss N12.06 billion in the first 6 months of year 2018 despite all efforts by the regulatory authorities to curb financial fraud and clean up the banking system. Nigerian Banks recorded 20,768 cases costing them 19.77 billion between Januarys June 2018. It was made known by the CBN who reported the fraud and forgery incidence that were perpetrated by both banks and non-banks staff. In the period under review, the actual loss by banks to fraud and forgery, however amounted 12.06billion compare with 0.78 billion and 0.03 million suffered in the first half of 2017. CBN said the cases involved armed robbery attacks, fraudulent ATM withdrawals, 27 draft defalcation, and illegal fund transfer, pilfering of cash, stealing, suppression and conversion of customers' deposits. Zenith Bank Plc lost 2.9million. business insider Financial statement for half year 2018 also showed a recorded 44 ATM/Electronic Fraud, nine fraud cases perpetrated by the bank staff, eight impersonation account, forty-five stolen and forged instrument, two internet banking fraud, while others fraudulent activities account for 43 . The bank robbery that occurred in Offa Kwara State Nigeria is another prominent issue in fraud and forgery cases which occurred in April 2018. Five Banks were attacked in Offa communities and went away with unspecified amount of cash in different currencies. Nigerian Deposit Insurance Corporation (NDIC,2018).

\section{THEORETICAL REVIEW}

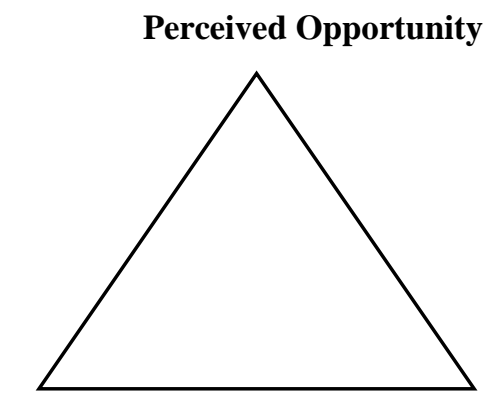

Perceived Pressure

Rationalization

Fig. 1 The Fraud Triangle

Source: Wells, J. T., 2005. The Principles of fraud examination. Hoboke,New York: John Wiley and Sons.

The fraud triangle theory was originated from Donald Cressey's hypothesis who concentrated his studies on 
embezzlers in 1950, who he called "trust violators". He was especially interested in the circumstances that led to be overcome by temptation. He developed what still remains as the classic model for the occupational offender. It consists of three components of which one leg of the triangle represent a perceived pressure (or non-shareable financial need). The second leg represents perceived opportunity, and the final leg denotes rationalization (Wells 2011).

In 1953, Cressey published his research in a book called "Other People's Money".

$\mathrm{He}$ divided the pressure or non-sharable financial problems into six categories: difficulty in paying back debts, problems resulting from personal failure, business reversals (uncontrollable business failures such as inflation or recession), physical isolation (trust violator is isolated from people who can help him), status gaining (living beyond one's means, and employer-employee relations (employer's unfair treatment).

Opportunity to commit fraud, conceal the fraud or avoid being punished forms the second element of the fraud triangle. The third element is rationalization which entails giving unnecessary explanation(s) to justify one's involvement in fraud. There exists pressure, motivation or compulsion on the fraudster who identifies opportunity which he utilizes and tries to justify his actions by unnecessary rationalization.

The fraud diamond theory, an expanded version of the fraud triangle theory, was first presented by Wolfe and Hermanson (2004). The fraud diamond theory includes an additional element: capacity. Wolfe and Hermanson (2004) argued that, although perceived pressure or incentive might coexist with an opportunity to commit fraud and a rationalization for doing so, fraud is unlikely to take place unless the fourth element, capacity, is also present. In other words, the potential

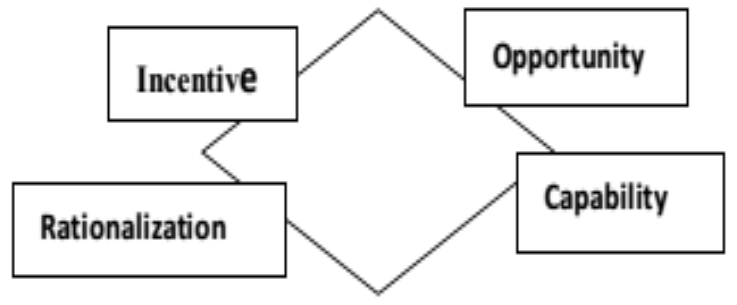

Fig. 2 The Fraud Diamond Model

Source: Wolfe, D. T. and Hermanson, D. R. (2004). "The fraud diamond: Considering the four elements of fraud".

perpetrator must have the skills and ability to actually commit fraud. Wolfe and Hermanson (2004) identified four observable traits related to individuals' capacity to commit fraud:

- Authoritative position or function within the organization

- Capacity to understand and exploit the accounting and internal control systems' weaknesses to the greatest advantage

- Confidence that fraudulent behaviors will not be detected (or that one can easily escape punishment if the behavior is detected)

- Capability to effectively deal with stress in order to manage the fraud over a long period of time.
The additional element presented in the fraud diamond theory affecting individuals' decision to commit fraud, the organization and forensic accountant need to better understand employees' individual traits and abilities in order to assess the risk of fraudulent behaviors. In addition, better systems of checks and balances should be implemented and monitored to proactively minimize risks and losses as a result of fraudulent activities in the workplace. The theoretical analysis of this study in relations to the effect of fraud on banks efficiency and customers deposit shall be based on this theory.

The fraud scale theory was developed by Albrecht, Howe, and Romney (1984) as an alternative to the fraud triangle model. The fraud scale is very similar to the fraud triangle; however, the fraud scale uses an element called "personal integrity" instead of rationalization. This personal integrity element is associated with each individual's personal code of ethical behavior. Albrecht et al. (1984) also argued that, unlike rationalization in the fraud triangle theory, personal integrity can be observed in both an individual's decisions and the decision-making process, which can help in assessing integrity and determining the likelihood that an individual will commit fraud. This argument is consistent with other research. It was discovered that fraud and other unethical behaviors often occur due to an individual's lack of personal integrity or other moral reasoning as moral and ethical norms play essential roles in an individual's decisions and judgment.

It was also observed that those who are interested primarily in "'beating the system" committed larger fraud but those who believed their pay was not adequate committed primarily small fraud.

Abdullah \& Mansur, 2015 opine that the opportunity to commit fraud is possible when employees have assets and information that allows them to both commit and conceal fraud. Opportunity are provided by a weak internal control environment, lack internal control procedures, failure to enforce internal control and various other factors such as apathy, ignorance, lack of punishment and inadequate infrastructure (ACFE, 2010).Access must therefore be limited to only those systems, information and asset that are truly necessary for an employee to complete his or her job. The third driver of fraud is ability of the perpetrators to find a way rationalize their actions as acceptable. Rationalization or absence of guidance regards to manner in which people think about their performance within the work place ( Nwaeze, 2008). He attach a value that they should derive from the company for being productive or delivering something of value. Absence of guidance on the other hand refers to the situations where there are limited or no processes in the organization to test the integrity of the financial information or processes. The absence of the integrity process includes an absence or ineffective role of internal auditors, external auditors, board of directors and reporting requirements.

\section{EMPIRICAL REVIEW}

Afayi (2014) examine the effect of fraud on the performance of banking industry in the United States of America (USA). Banking industry as a whole were examined and this give answers to why bank failed, examined how 
many banks have failed or what percentage of banks have failed in USA as a result of fraud, scrutinized the protective measures the banking industry were taken to prevent fraudulence practices and list any corrective action if need be. The study spanned from 2000 - 2014 in which about 523 banks have failed throughout USA. In method used, the ratio of bank failure caused by fraud as opposed to other factors out of 20 selected banks, 8 banks representing 40 percent failed due to fraudulent practices.

Yunsen, Song and Yutao (2011) explored corporate fraud and bank loans in China. It investigated the effect of corporate fraud on bank loans by investigating firms' credit and information risks, thus extending research on the economic consequences of corporate fraud. It also examined banks' lending behaviour after corporate fraud. Findings revealed that receiving punishment from regulators for corporate fraud can affect financing contract between a firm and its bank, as both the firm's credit risk and information risk increase after punishment. Also, firms' bank loan after punishment are not only significantly lower but were also less than non-fraudulent firms. The loan interest rates after punishment were not only higher than before but also higher than non- fraudulent counterparts. Corporate fraud destabilizes the 'performance- bank loan' relationship.

Kanu and Okorafor (2013) reviewed various forms of fraudulent practices and their impact on bank deposits in Nigerian banks between 1993 and 2010. They investigated the amount of banks lost to frauds and related it to total deposit liabilities of insured money bank in Nigeria. They used descriptive and inferential statistics in the study. It was revealed that there existed significant relationship between bank deposits and amount lost to fraud with fraudulent withdrawals constituting the bulk of the fraud. Similarly, Aruomoaghe and Ikyume (2013) examined fraud using descriptive survey research. It was discovered that non accounting for fraud in the organizations financial statement do not reflect a true and fair view of such financial statement and may mislead the users of such financial statement.

Uchenna and Agbo (2013) evaluated the impact of fraud and fraudulent practices on the performance of banks in Nigeria for the period 2001 - 2011. Twenty-four deposit money banks (commercial banks) in Nigeria were used for the study looking at the nature, magnitude and economic consequences of fraud in Nigeria. Pearson product moment correlation was used to ascertain the relationship between the variables while multiple regression analysis was adopted for analysis of compact of fraud and fraudulent practices or performance of Nigerian banks. It was discovered that the percent of mobilized fund lost to fraud was highest between 2001 and 2005 but there was significant decrease between 2006 and 2011.

Furthermore, Owolabi (2010) reviewed various forms of fraudulent practices, their impact and inducement for various forms of reform in the industry between 2002 and 2006. He adopted descriptive research design. He found out that managers and supervisors involvement in bank fraud accounted for 485 (37\%); Executive officers/Accountants and Executive Assistants 431 (33.59\%) totaling 916 out of 1,283 employees involved in the fraudulent act.
Inaya and Isito (2016) investigated the social impact of fraud on the Nigerian banking industry. Ex-post facto research design was adopted for the study. Data were collected from Nigerian Deposit Insurance Corporation and commercial bank statement of account for the period 1990 2014. Ordinary least square (OLS) with its least linear unbiased estimate (BLUE) property was used in analyzing the data. They discovered that bank in Nigeria thrive under high rate of fraud and fraud has negative social impact on Nigerian banking industry.

\section{METHODOLOGY}

The research design used for this study is the descriptive method as the study entails the use NDIC annual reporters. The population of this study consisted of all commercial banks/ MDBs in Nigeria. For the purpose of this study five banks will be selected as sample using purposive sampling technique method which is also known as judgmental and selective sampling techniques as a means of meeting the criteria set for bank under study. The selected banks are those that have the following criteria.

(a) The bank must be listed on the Nigerian stock exchange.

(b) The bank must have at least Ten (10) years financial information.

The five selected banks are as follows:

1. United Bank for Africa Plc

2. Union Bank Plc

3. Wema Bank Plc

4. Fidelity Bank Plc

5. First Bank Plc

The source of data for this study was secondary data obtained from Nigeria Deposit Insurance Corporation on a quarterly basis in relation to the five purposively selected DMBs in Nigeria. In term of scope, the study covered the period 2008 to 2017 . These periods were selected due to the fact that it was these periods that reported cases of frauds were rampant I Nigeria Deposit Money Banks. This study made used of Generalized Method of Moment (GMM).

\section{A. Model Specification}

The objective of the study is to investigate the impact of fraud on Bank's efficiency and customer deposit in Nigeria from 2008 to 2017 . Hence, the model for this study is a slight modification of the one found in Ikpefan (2006), and can be stated mathematically as:

$\mathrm{BD}_{\mathrm{t}}=\beta_{\mathrm{o}}+\beta_{1} \mathrm{ARFC}_{\mathrm{t}}+\beta_{2} \mathrm{ALF}_{\mathrm{t}}+\beta_{3} \mathrm{NSIF}_{\mathrm{t}}+\beta 4 \mathrm{BE}_{\mathrm{t}}+$

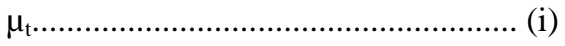

Where,

$\mathrm{ARFCt}=$ Amount involved in reported fraud cases at time $\mathrm{t}$ $\mathrm{ALF}_{\mathrm{t}}=$ Amount lost to fraud at time $\mathrm{t}$

$\mathrm{NSIFt}=$ Number of staffs involved in fraud cases at time $\mathrm{t}$. $\mathrm{BEt}=$ Bank Efficiency proxied as Profit Before Tax at time t.

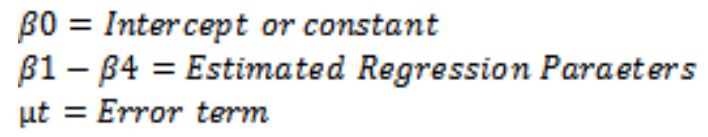

A priori expectation for this model used to capture the objective on the effect of fraud on bank deposit was;

$\beta 1<0, \beta 2<0, \beta 3<0$ and $\beta 4<0$ 
By introducing dynamism to the model in equation 1 above, we predict that the previous bank deposit can determine present bank deposit. Therefore, equation (1) transformed into a dynamic model is expressed as:

$\mathrm{BD}_{\mathrm{t}}=\beta_{0}+\alpha \mathrm{BD}_{\mathrm{t}-1}+\beta_{2} \mathrm{ARFC}_{\mathrm{t}}+\beta_{3} \mathrm{ALF}_{\mathrm{t}}+\beta_{4} \mathrm{NSIF}_{\mathrm{t}}+$ $\beta 5 \mathrm{BE}_{\mathrm{t}}+\mu_{\mathrm{t}}$

Where,

$\mathrm{BD}=$ contemporaneous bank deposit;

$\mathrm{BD}_{\mathrm{t}-\mathrm{l}=}$ the lagged value of bank deposit by one

Note that, $\alpha$ is the regression parameter attached to lag vale of bank deposit and it was expected to be positive

Moreover, to achieve the second objective of tis paper on the impact of fraud on bank efficiency, the mathematical model in equation two is modified as;

$\mathrm{BEt}=\beta_{0+} \beta 1 \mathrm{BDt}+\beta 2 \mathrm{BD}_{\mathrm{t}-1}+\beta_{3} \mathrm{ARFC}_{\mathrm{t}}+\beta_{4} \mathrm{ALF}_{\mathrm{t}}+\beta_{5} \mathrm{NSIF}_{\mathrm{t}}$

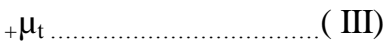

Where,

$\mathrm{BEt}=$ Bank Efficiency at time $\mathrm{t}$, proxied by reported Profit Before Tax (PBT) at the selected DMBs.

All other independent variables in the model remained as earlier defined.

A priori expectation for this equation 3, was that;

$\beta 1>0, \beta 2>0, \beta 3<0, \beta 4<0$, and $\beta 5<0$

\section{PRESENTATION OF RESULTS/ FINDINGS}

The results obtained for this were presented below

Table 1 GMM Results for achieving the effect of fraud on Customers Deposit

\begin{tabular}{|c|c|c|c|c|}
\hline Variable & Coefficient & Standard Error & T-Calculated & P.Value \\
\hline $\mathrm{C}$ & 1251.430 & 2278.0699 & 0.549338 & 0.7631 \\
\hline BDt-1 & 1.113559 & 0.182919 & 6.087703 & 0.0000 \\
\hline N S IF & -0.170866 & 0.068434 & -2.496800 & 0.0375 \\
\hline ARFC & -0.082227 & 0.019275 & -4.265992 & 0.0001 \\
\hline A L F & -0.406678 & 0.085206 & -4.772880 & 0.0000 \\
\hline $\mathrm{PB} \mathrm{T}$ & -18.53729 & 17.70541 & -1.046985 & 0.3025 \\
\hline & OTHER & TEST & STATISTICS & \\
\hline R-squared & 0.787685 & & Mean dependent var & 3898.732 \\
\hline Adjusted Rrspluared & 0.756462 & & S.D. dependent var & 1890.264 \\
\hline SE. of regression & 932.8375 & & Sum squared resid & 29586315 \\
\hline Durbin-Whason stat & 2.248562 & & J-statistic & 89.678300 \\
\hline Instrument rank & 6 & & Prob (J-Stat) & 0.0000000 \\
\hline
\end{tabular}

Source: Researcher's computation, 2019 (E-View 9)

\section{RESEARCH RESULTS DISCUSSION}

The results of the Generalized Method of Moment computed for achieving the objectives one to three was presented in Table 1. Looking at the result from the table, it was discovered that the p-value of the t-statistics computed for Bank Deposit at the lagged year of 0.0000 was less than the critical value of $5 \%$. This implied that the null hypothesis which stated that bank deposit in the lagged year was not significance on the bank deposit in the current year was rejected. The resultant effect of this was that bank deposit in the previous year determined to a large extent bank deposit in the current year. The implication of this was that whatever happened to bank deposit in the previous year might make or mar the bank deposit in the current year. As posited by Popoola et al. (2018) that the consequence of fraudulent activities on bank deposit in the lagged year might determine to a large extent the bank deposit in the current year. Deposit according to Osuala, Opara and Okoro (2016) were hold in trust by the bank for customers and the imperative of fraud in a bank might determine whether these deposit were saved or not. Therefore, the lagged period of bank deposit determined to a great extent the current year deposit. More so,the regression coefficient obtained for bank deposit in thelagged period of 1.11 was positive with significant t-statistics

Table 2 GMM Results for the effect of fraud on bank efficiency

Dependent Variable $=$ Bank efficiency proxy as PBT

\begin{tabular}{|c|c|c|c|c|}
\hline Variable & Coefficient & Standard Error & T-calculated & P-value \\
\hline $\mathrm{C}$ & 4.635629 & 3.003188 & 1.543569 & 0.1320 \\
\hline $\mathrm{BD}$ & 0.001660 & 0.001469 & 1.129688 & 0.2665 \\
\hline BDt-1 & 0.004978 & 0.001751 & 2.842995 & 0.0075 \\
\hline NRCF & -0.009212 & 0.000757 & -12.17403 & 0.0000 \\
\hline ARFC & -5.516705 & 0.120248 & -45.877728 & 0.0000 \\
\hline ALF & -0.001988 & 0.002212 & -0.898415 & 0.3753 \\
\hline & OTHER & TEST & SIATISIICS & \\
\hline Resplaxed & 0.872179 & & IVenderatentiliz & 27.53575 \\
\hline lifithered & 0.853382 & & SD.jerendation & 23.05091 \\
\hline Sethexio & 8.826357 & & 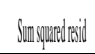 & 2648.756 \\
\hline Dirithing & 1.851233 & & J-statistic & 112.800045 \\
\hline 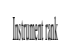 & 6 & & 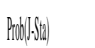 & 0.0000000 \\
\hline
\end{tabular}

Source: Researcher's computation, 2019 (E-view 9)

value of 6.09. This indicated that there was a positive relationship between bank deposit in the lagged year and that of the current year. The economic interpretation of this was that a $1 \%$ increase in bank deposit in the lagged year might result in $6.09 \%$ increase in their current year. The sign of this coefficient was in line with the priori expectation and hence, bank deposit in the lagged year might be a determinant of bank deposit in the current year.

Therefore, the p-value of the t-statistics computed for number of staff involved in fraud cases of 0.0375 was less than the critical value of $5 \%$. This indicated that the null hypothesis which stated that the number of staff involved in 
fraud cases was not significance on bank deposit was rejected. The consequence of this was that the number of staff involved in fraud cases was significance on bank deposit. As observed by Usman \& Shah (2013) that the numbers of staff involved in fraud cases might determine to a large extent the level of bank deposit. The implication of this was that the higher the numbers of staff involved in fraud cases the tendency was that the bank deposit might be seriously eroded. The activities of fraudulent bank officials had been observed by Udeh \& Ugwu (2018) to have a negative impact on bank deposit. The incidence of forged cheque, wrong money transfer, and intentional withdrawn of depositors funds by unscrupulous bank officials had serious repercussion on customers deposit. Substantial numbers of banks in Nigeria during pre-merger and acquisition periods were found to be unable to meet their customers demand and request as a result of frauds that had eroded the deposit of many of these banks. The regression coefficient computed for this test variable was -0.17 . This indicated an existence of a negative relationship between bank deposit and number of staff involved in fraud case. The economic implication of this was that a $1 \%$ improvement in the numbers of staffs involved in fraud cases could lead to $0.17 \%$ reduction in bank deposit. The sign of this variable was in tandem with a priori expectation for the variable and hence, NSIF might be a determinant of bank deposit.

Moreover, it was discovered that the p-value of the $\mathrm{t}$-statistics computed for amount involved in reported fraud cases of 0.0001 was less than the critical value of $5 \%$. This revealed that the null hypothesis which stated that the amount involved in reported fraud cases was not significance on bank deposit was rejected. It was reasonable to assert that the amount involved in reported fraud cases was significance on bank deposit. It was essentially true that sufficient numbers of fraud committed by unscrupulous bank officials affected bank deposit seriously. This was because frauds committed were committed on customers' deposit. These fraudulent activities might come in form of intentional wrong transfer, forged cheque, deliberate wrong entry and deposit balance manipulation. As posited by Udeh \& Ugwu (2018) that the resultant effect of fraud on customers deposits could not be underestimated. In fact, the higher the amount involved in fraud case the more the bank deposit might shrink. Fraud affected the ability of deposit money banks to meet their customers demand. It eroded the confidence of the shareholders in the ability of the management to safe guide their shares. It affected the continuous patronage of customers of the banks where frauds were rampant. Consequently, with customers deposit eroded, the affected bank might be loosed its license or went into insolvency. The regression coefficient obtained for this variable was -0.08. this showed an existence of a negative relationship between ARFC and bank deposit. The interpretation of this was that a $1 \%$ increase in amount involved in fraud cases might lead to $0.08 \%$ reduction in bank deposit. The sign of this variable was in conformity with the priori expectation and hence ARFC might be a determinant of bank deposit.

In addition, the p-value of the t-statistics computed for Amount loss to Fraud of 0.0000 was less than the critical value of $5 \%$. This indicated that the amount loss to fraud was significant on bank deposit. The amount loss to fraud might have a substantial effect on bank deposit and hence, affecting the ability of a bank to meet its customers demand without resulting to borrowing from the interbank. The incidence of frauds could lead to loss of customers' deposit. This was because these frauds were usually targeted at depositors' funds. In fact, over 65 billion was reported by the NDIC to be lost to fraud in the second quarters of the year 2019. This according to the report had affected the ability of some new generation banks to meet their customers demand in terms of withdrawal, and loans and advances request without resorting to borrowing from the interbank and Central Bank of Nigeria. This resultant showed that the amount lost to frauds had a greater influence on customers deposit in a bank and could lead to complete loss of depositors' funds in serious cases. The regression coefficient obtained for this test variable was -0.41 . This revealed that there was a negative relationship between bank deposit and amount loss to fraud cases in DMBs. The interpretation of this was that a unit increase in the amount loss to fraud cases in the DMBs in Nigeria might lead to $0.41 \%$ reduction in bank deposit. The sign of this variable was in conformity with the priori expectation and hence, the variable might be a determinant of bank deposit.

In effect, it was found that the p-value of the t-statistics computed for profit before tax of 0.3025 was greater than the critical value of $5 \%$ with insignificant t-statistics value of -1.05 . This indicated that the null hypothesis which stated that PBT was not significant on bank deposit was accepted. The implication of this was that PBT did not directly influenced the bank deposit of DMBs. Profit Before Tax was as a result of operational activities of the bank through effective customers derivers, increasing sales of bank products, increasing customers activities on POS, ATM, online bank and internet transaction. With the right charges on bank operation the efficiency of bank was ensued. Profit Before Tax did not add positively to bank deposit but reduced it. This was because the money kept as liabilities by banks were being depleted on daily basis as a result of bank charges on them. Moreover, the regression coefficient computed for PBT was -18.54. This indicated a negative relationship between PBT and bank deposit. This affirmed that there was an indirect relationship between PBT and bank deposits. The resultant effect of this was that a $1 \%$ increase in PBT might lead to $18.54 \%$ reduction in bank deposit. This was because charges on these deposits formed the bulk of funds declared as profit by these banks. The sign of this variable was in tandem with the priori expectation and hence, the variable might be a determinant of bank deposit.

The results of other test statistics computed for the these objectives such as coefficient of determination $\left(\mathrm{R}^{2}\right)$, Durbin-Watson Statistics, and J-statistics indicated that the independent variables of the study might be good predictor variables for bank deposit. For instance, the coefficient of determination obtained of 0.7877 revealed that approximately $79 \%$ of bank deposit in Nigeria DMBs was explained by Bank deposit in the lagged year, number of staff involved in fraud, amount involved in reported fraud cases, amount lost to fraud and PBT. In continuation, the p-value of the J-statistics computed of 0.0000 was less than the critical 
value of 5\%. This indicated that the joint null hypothesis for this test was rejected. It was reasonable to infer that the independent variables of the regression model exerted serious influenced on bank deposit. The Durbin-Watson statistics computed for the test of 2.248562 showed that all the variables of the study were free from serial correlation.

Table 2, presented the results of the GMM computed for achieving the effect of numbers of reported cases of fraud on bank efficiency. From the table, it was found that the p-value of the t-statistics computed for bank deposit of 0.1320 was greater than the critical value of $5 \%$. This indicated that the null hypothesis which stated that bank deposit was not significance on bank efficiency was accepted. The implication of this was that bank deposit had no substantial effect on bank efficiency. This was because bank deposit was a liability to deposit money bank and any lost resulting from these depositors funds might not be accepted by the customers. In fact, it was the responsibility of bank to ensure that the customer deposit in their care were properly safe guide from lost due to fire, theft, fraudulent activities and financial negligence. The regression coefficient computed for bank deposit of 0.002 was positive with an insignificant $\mathrm{t}$-statistics value of 1.13 . This revealed that there was a positive relationship between bank deposit and bank efficiency and hence, a $1 \%$ increase in bank deposit might result in $0.002 \%$ improvement in bank efficiency as regarding reported profit before tax. The sign of this variable was in conformity with a priori expectation for the variable.

It was found that the $\mathrm{p}$-value of the t-statistics computed for bank deposit in the lagged year of 0.0075 was less than the critical value of $5 \%$. This implied that the null hypothesis which stated that bank deposit in the lagged year was not significance on bank efficiency was rejected. The implication of this was that bank deposit in the lagged year was significance on bank efficiency. This might be due to the fact that the lagged year period had inadequate number of reported cases of frauds that might affect the bank deposit seriously. With few incidences of frauds cases in the previous year the efficiency of the DMBs in term of PBT might be enhanced. This was because enough bank charged and other fees that helped profitability position of the selected DMBs might be collected in the lagged year. The regression coefficient obtained for this variable was 0.005 with significance $\mathrm{t}$-statistics value of 2.84 . this showed that there was a significance positive relationship between bank deposit in the lagged year and bank efficiency. The interpretation of this was that a $1 \%$ increase in bank deposit in the previous year could lead to $0.005 \%$ improvement in bank efficiency in the current year. The sign of this variable was in tandem with the priori expectation and hence, bank deposit in the lagged year might be a determinant of bank efficiency in the current year.

Furthermore, it was discovered that the p-value of the number of reported cases of fraud of 0.0000 was less than the critical value of $5 \%$. This showed that the hypothesis which stated that the number of reported cases of frauds was not significance on the bank efficiency was rejected. It was reasonable to assert that the number of reported cases of frauds was significance on bank efficiency. The efficiency of bank in term of reported PBT, internal control efficiency and other performance indicators might be affected with greater number of reported cases of frauds. No sanity customers would continue to patronize a bank that was already known that fraud cases were rampant there. Bank efficiency would be eroded due to customers loss of confidence in the bank management to safe guides their deposit. Shareholders confidence would be affected and the general public might lose interest in the shares of these banks that had high numbers of fraud cases. The regression coefficient computed for this variable was -0.009 with significance $t$-value of -12.17. This indicated that there was a significance negative relationship between number of reported fraud cases and bank efficiency. The import of this was that a $1 \%$ increase in cases of fraud in the selected DMBs might lead to $0.009 \%$ reduction in the efficiency of these banks. The sign of this variable was in conformity with a priori expectation and hence, this parameter might be a determinant of bank efficiency.

It was discovered that the p-value of the amount of reported fraud cases computed was 0.0000 less than the critical value of $5 \%$. This showed that the null hypothesis which stated that the amount of reported fraud cases was not significance on the selected bank efficiency was rejected. The implication of this was that the amount reported for fraud cases affected bank efficiency. The efficiency of a bank in term of reported profitability would be affected if amount of money reported to be involved in fraud was through high. The higher the amount reported in fraud cases the lower might be the tendency of these banks to achieve their expected profitability level. This was because substantial amount of profit realized might be used as buffer to safe-guide funds loss to frauds. The regression coefficient computed for this test item was -5.52 . This revealed that there was a negative correlation between amount reported as fraud and bank efficiency. The appropriate interpretation of this was that a unit increase in the amount reported as fraud might lead to $5.52 \%$ reduction in bank efficiency. The sign of this variable was in conformity with a priori expectation for the variable.

Resultantly, it was found that the p-value of the t-statistics computed for amount loss to fraud of 0.3753 was greater than the critical value of 5\%. This implied that the null hypothesis which stated that amount loss to fraud was not significance on bank efficiency was rejected. The implication of this was that the amount lost to fraud in the current year was not substantially impactful on bank efficiency. Although, the amount lost to fraud might had a serious effect on bank efficiency in relation to PBT, it was reasonable to infer that due to mechanism put in place by these DMBs the amount lost to fraud was not seriously impactful on bank efficiency. The import of this was that the selected banks had made adequate provision to safe guided against any eventuality as a result of funds lost to fraud. The regression coefficient obtained for this test variable was -0.002 . This showed that there was a negative relationship between amount lost to fraud and bank efficiency. The economic interpretation of this was that a $1 \%$ increase in the amount lost to fraud might lead to $0.002 \%$ reduction in bank efficiency and hence, amount lost to fraud and bank efficiency were inversely related. The sign of this variable conform to a priori expectation for the 
parameter. This parameter might be a determinant of bank efficiency.

The results of the other test statistics computed for the test of hypothesis indicated that the independent variables of the study were better predictor for bank efficiency. For example, the coefficient of determination $\left(\mathrm{R}^{2}\right)$ obtained for the test of -0.87 indicated that $87 \%$ of bank efficiency was caused by the explanatory variables of the model. In addition, the $p$-value of the J-statistics computed for testing the overall joint hypothesis which stated that number of reported cases of fraud was not significance on bank efficiency of 0.0000 was less than the critical value of $5 \%$. This implied that $t$ nu8mber of reported cases of fraud was significance on bank efficiency. Also, the Durbin-Watson Statistics computed for the test of 1.851233 revealed that the variables of the study were free from serial correlation.

\section{Contribution to Knowledge}

This study had effectively contributed to knowledge in the field of banking fraud. The study had showed that incidence of fraud in Nigeria commercial banks affected the bank deposit. This was quite different from the finding of Uchenna and Agbo (2013) that posited that fraud had no sufficient impact on customers' deposit. Their finding might be due to insufficient numbers of years (2009-2011) they used for the study. Therefore, this study had revealed that with appropriate numbers of observation a balance result might be obtained.

Moreover, the study had indicated that the number of reported cases of fraud was significance on bank efficiency. It further revealed that with incidence of fraud the bank efficiency in relation to performance indicators might shrink. Also, the study had pin point the fact that with robust statistical tool such as Generalized Method of Moment (GMM) a reasonable result might ensue.

\section{CONCLUSIONS}

This study had revealed that the incidence of fraud in deposit money banks might erode bank deposit and consequently affect the efficiency of DMBs in term of reported profitability and other performance indicators. Hence, based on the finding of this study, the following conclusions were made.

- There was sufficient evidence that the incidence of fraud in Nigeria Deposit Money Banks negatively affected the bank deposit.

- There was a significant negative effect of fraud on bank efficiency. With fraud committed through deliberate wrong entry, forged cheque and manipulation of accounting records, it was certain that the efficiency of DMBs in Nigeria in term of certain performance indicators might not be encouraging.

\section{Recommendations}

The following recommendations are made.

- There is need for bank management in Nigeria to continue to put in place strong internal control system that will ensure that the incidence of fraudulent cases in Nigeria DMBs is reduced to a bare minimum if not totally eliminated.

- Bank efficiency may be hampered if appropriate control system was not put in place to reduce incidence of fraud in the Nigerian Deposit Money Banks, hence, there is need for management of the Nigerian DMBs to ensure that the right staffs were put in charge of financial transactions of their banks in order to reduce persistently fraud scenario in these banks.

\section{Suggestion for Further Studies}

More studies can be carried out on the effect of fraud on profit after tax of DMBs in Nigeria. The relationship between frauds, internal control system and organization effectiveness may be considered in another study. The relative efficiency of fraud and its implication on customers loyalty may be dome in future study. The implication of frauds on staff turnover in Nigeria manufacturing company may be researched further in another study.

\section{REFERENCES}

[1] Abdullahi, R. \& Mansor, N. (2015). Forensic Accounting and Fraud Risk Factors: The Influence of Fraud Diamond Theory. The American Journal of Innovative Research and Applied Sciences. 1 (5), 186-192.

[2] Adebayo, O. G. \& Topson, A. O. (2014). Bank Frauds and Forgeries in Nigeria: A Study of the Causes, Types, Detection and Prevention. IOSR Journal of Economics and Finance, 4 (2), 41-50 www.iosrjournals.org

[3] Adeyemo, K. A. (2012). 'Frauds in Nigerian Banks: Nature, Deep-seated causes, Aftermaths and Probable Remedies' Mediterranean Journal of Social Sciences, 3 (2), 64-72

[4] Akindele, S. T. (2005). "A Critical Analyze of Corruption and its Problems in Nigeria" Anthropologist, 7 (1), 7 - 18

[5] Ademoye, K. A. (2012). Frauds in Nigerian banks: Nature, deep-seated causes, aftermaths and probable remedies, Doi:10.5901/mjss.2012.v3n2.279.

[6] Afayi, T. (2014). The effect of fraud on the performance of banks in the United States of America, https//www.academia.edu

[7] Albrecht, W. Steve; Howe, Keith R.; Romney, Marshall B. (1984), Detering fraud: the internal auditors perspective. The Institute of Internal Auditors Research Foundantion, Altamonte Springs, Florida.

[8] American Institute of Certified Public Accountants (AICPA), (2002). Statement of auditing standards 99 consideration of fraud in financia statement audit. New York, NY: American Institute of Certified Public Accountants.

[9] Aruomoaghe, J. A. \& Ikyume, J. C. (2013). Accounting for fraud in Nigeria: The banking sector in focus, International Journal of Research in Management 3(6), 59-73.

[10] Asukwo, P. E. (1999). Bank Frauds: A Look at the Nigerian Banking Cleaning System. ICAN News, 4 (1), $16-19$

[11] Central Bank of Nigeria (2014). Statistical bulletin.,25.

[12] Cressey, D. R. (1971). Other peoples' money: A study in social Psychology of embezzlement. Glencoe, Free Press.

[13] Economic \& Finanacial Crimes Commission (EFCC) Establishment Act (2004) https://efccnigeria.org/efcc/index.php/about-efcc/the-establishment-ac t.

[14] Enofe, A. O, Abilogun, T. O, \& Omoolorun, A. J, (2017) Bank Fraud and Preventive Measures in Nigeria: An Empirical Review. Inter $\mathrm{J}$ Academic Res Business Social Sci. 7 (42).

[15] Idowu, A. (2009). An assessment of fraud and its management in Nigeria commercial banks. Journal of Social Science, 10(4), 21-29.

[16] Ikpefan, O.A. (2006). Growth of bank frauds and impact on Nigerian banking Enprint.convenantuniversity.edu.ng/1316/1/fraud.pdf

[17] Imoniana, J. O., Antunes, M. T. P. \& Formgoni, H. (2013) Forensic accounting and corporate fraud, Journal of Information Systems and Technology Management 10(1).

[18] Inaya, L. \& Isito, E. O. (2016). An empirical analysis of social impact of fraud on the Nigerian banking industry, Research Journal of Finance and Accounting 7(4), 12-17. 
[19] Kanu, S. I. \& Okorafor, E. O. (2013). The nature, extent and economic impact of fraud on bank deposits in Nigeria, Interdisplinary Journal of Contemporary Research in Business 4(9), 253- 265

[20] KPMG (2009). Fraud survey 2009: Integrity survey. http://www.kpmg.com/aci/docs/insights/21001NSS fraud survey 082409.pdf Accessed 26/04/16.

[21] Nigerian Deposit Insurance Corporation (NDIC) Annual Reports. www.ndic.gov.ng. Nigerian Deposit Insurance Corporation (NDIC), 2018 www.ndic.gov.ng /wp/content/uploads/2015/07/link/parttwo/pdf.

[22] Nwaeze, M. O. (2008). Towards curbing commercial bank fraud: An analysis of internal control. A postgraduate dissertation submitted to the department of financial studies, university of Nigeria, Nsukka.

[23] Nwaze (2012). Due process and accountancy: Advanced fee fraud (1) Zenith Economic Quarterly 8(2) 24-28.

[24] Ojo, J. A. (2008). Effect of bank fraud on banking operations in Nigeria, International Journal of Investment and Finance 1(1), 103

[25] Okoye, E. I. \& Gbegi, D. O. (2013). Forensic Accounting: A tool for fraud detection and prevention in the public sector (A study of selected Ministries in Kogi State), Journal of Academic Research in Business and Social Sciences, 3(3)

[26] Olatunji, O. C. \& Adekola, D. A. (2014).analysis of frauds in banks: Nigeria's experience European Journal of Business Management 6(31), 90-99.

[27] Osuala, A. E., Opara, C. C., \& Okoro, C. E. (2016). The impact of fraud on the risk assets of Nigerian commercial banks. Journal of Finance and Economic Research, 3(1), 81-96.

[28] Owolabi, S.A. (2010). Fraud and fraudulent practices in Nigerian banking industry, An International Multi-Disciplinary Journal, Ethiopia 4(3b), 240-256.

[29] Popoola, A.F.. Fakunle, I. A., Omole, I. I. \& Oyedeji, O. (2018). Bank Fraud and Its Effect on Nigerian Economy: A Study of Selected Quoted Banks. European Journal of Accounting, Auditing and Finance Research, 6 (8), 104-120

[30] Shogunle, E. (2012). "The Challenges of Eradicating Corruption in Nigeria: What Options?" A Paper Presented at the 2nd National Policy Conference on Transparency and Accountability in the Public Sector at Abuja Uchenna

[31] Tchankova, L. (2002). Risk identification-basic stage in risk management. Journal of Environmental Management

[32] Uchenna, C. \& Agbo, J.C. (2013). Impact of fraud and fraudulent practices on the performance of banks in Nigeria, British Journal of Arts and Social Sciences 15(1), 12-28.

[33] Udeh, S. N., \& Ugwu, J. I. (2018). Fraud in Nigerian Banking Sector. International Journal of Academic Research in Business and Social Sciences, 8(5), 589-607.

[34] Usman, A. K. \& Shah, M. H. (2013). Critical success factors for preventing e-banking fraud. Journal of Internet Banking and Commerce, 18(2), $1-54$.

[35] Wanjohi, M. W. (2014). Fraud in the banking industry in Kenya: A case study of commercial bank of Africa, Kenya. (MBA Thesis). United States International University Africa.

[36] Wells, J. T. (2005). New approaches to fraud deterrence. Journal of Accountancy, 197(2), 72-76.

[37] Wolfe, D. T. and Hermanson, D. R. (2004). "The fraud diamond: Considering the four elements of fraud", The CPA Journal, p.4 